\title{
EFFECT OF INTEGRATED WEED MANAGEMENT AND BALANCED FERTILIZATION ON WEED DYNAMICS IN CORIANDER
}

\author{
(CORIANDRUM SATIVUM L)
}

\author{
RAJ KUMAR NAGAR \& DINESH KUMAR JAIN \\ Department of Agronomy, Rajasthan College of Agriculture, Maharana Pratap \\ University of Agriculture and Technology, Udaipur, Rajasthan, India
}

\begin{abstract}
A field experiment was conducted at Instructional Farm, Rajasthan College of Agriculture, Udaipur (Rajasthan) to determine the weed dynamics, in coriander and their effect on seed yield. Pooled analysis of two year data indicated that, among eight weed species reported in the field Chenopodium murale, Spergula arvensis and Cyperus rotundus were found most, dominating weed species and comprises more than 50 percent of total weeds, at all stages of crop growth. All weed management practices significantly reduced the density and dry matter of all weed species and improve the weed control efficiency and seed yield of coriander, as compared to control. Two $\mathrm{HW}$ at 30 and 45 DAS resulted in maximum reduction, in weed density and dry matter, and resulted in highest seed yield (15.84 q/ha) of coriander. However, at par seed yield was obtained by another treatment of pendimethalin $1.0 \mathrm{~kg} / \mathrm{ha}+$ one hand weeding at 45 DAS. Both the treatments also remained, at par in reduction of weed dry matter and resulted in maximum weed control efficiency, as compared to rest of practices. Balanced fertilization with $60 \mathrm{~kg} \mathrm{~N}+30 \mathrm{~kg} \mathrm{P+30} \mathrm{kg} \mathrm{K}+30 \mathrm{~kg}$ S/ha also significantly improved weed dry matter, but also simultaneously enhanced the seed yield of coriander, over $N+P$ and $N+P+K$ application. Interactive effect of weed management and balanced fertilization was also found significant, in respect of monocot weed dry matter, at $90 \mathrm{DAS}$ and seed yield of coriander. A pre-emergence application pendimethalin $1.0 \mathrm{~kg} / \mathrm{ha}$, followed by one $\mathrm{HW}$ at $45 \mathrm{DAS}$ and fertilization with $60 \mathrm{~kg} \mathrm{~N}+30 \mathrm{~kg} \mathrm{P}_{2} \mathrm{O}_{5}+30 \mathrm{~kg} \mathrm{~K}_{2} \mathrm{O}+30$ $\mathrm{kg} \mathrm{S} / \mathrm{ha}$, would be recommended to achieve maximum weed control efficiency and higher seed yield, from coriander cultivation.
\end{abstract}

KEYWORDS: Coriander, Hand Weeding, Interaction, Weed Species, Integrated Weed Management, Pendimethalin \& Yield.

Received: Oct 10, 2017; Accepted: Oct 30, 2017; Published: Nov 09, 2017; Paper Id.: IJASRDEC201725

\section{INTRODUCTION}

Coriander (Coriandrum sativum L.), popularly known as its vernacular name "Dhania" is one of the oldest seed spices, consumed all over the world. It's extensively used in culinary preparations, manufacturing of curry powder, pickling spices, sausages, and seasoning, in confectionery apart from its use in medicines. The coriander seed oil is valuable ingredient, in perfumes and cosmetic products, liquors, cigarette and soft drinks. India is the largest producers of coriander, with a production of almost 90 percent of total world's supply. Despite significant contribution of coriander crop in human nutrition, export value and overall production of spices, the productivity of this crop has almost stagnant, which makes matter of great concern.

Among the all agronomic practices, inefficient weed control and imbalance fertilization have been 
recognized as major factor, for low productivity. Weeds appear to be the most serious menace, in crop production. Weed infestation during early stages of crop growth ends, in yield loss up to 60 percent in coriander; have been reported by Kushwaha et al. (2002). Use of pre-emergence herbicide alone or in combination with hand weeding, may be useful to economize the costly labour. To have higher productivity, nutrient management strategies are also equally important. Hence, an experiment was conducted to compare the effect of integrated weed management and balanced fertilization, on productivity of coriander.

\section{MATERIALS AND METHODS}

The field experiment was conducted, during winter seasons of 2002-03 and 2003-04 at Instructional Farm, Rajasthan College of Agriculture and Udaipur. The soil was clay loam having medium available N (276.83 kg/ha) \& available $\mathrm{P}(18.99 \mathrm{~kg} / \mathrm{ha})$, high K (365.54 kg/ha) and $\mathrm{S}(10.02 \mathrm{ppm}) \mathrm{pH}$ 8. Thirty-three treatment combinations, comprising 11 weed management practices in main plots [W1=weedy check, W2=one hand weeding (HW), at 30 DAS, W3=two HW at 30 and $45 \mathrm{DAS}$, W4= pendimethalin $1.0 \mathrm{~kg} / \mathrm{ha}$, W5=oxyfluorfen $0.25 \mathrm{~kg} / \mathrm{ha}$, W6=metribuzin $0.30 \mathrm{~kg} / \mathrm{ha}$, W7=oxadiargyl $75 \mathrm{~g} / \mathrm{ha}, \mathrm{W} 8=$ pendimethalin $1.0 \mathrm{~kg} / \mathrm{ha}+\mathrm{HW}$ at $45 \mathrm{DAS}$, W9= oxyfluorfen $0.25 \mathrm{~kg} / \mathrm{ha}+\mathrm{HW}$ at $45 \mathrm{DAS}, \mathrm{W} 10=$ metribuzin $0.30 \mathrm{~kg} / \mathrm{ha}+\mathrm{HW}$ at 45 and W11= oxadiargyl $75 \mathrm{~g} / \mathrm{ha}+\mathrm{HW}$ at $45 \mathrm{DAS}]$ and 3 balanced fertilization treatments, in sub plots $\left(\mathrm{F} 1=\mathrm{N}_{60}+\mathrm{P}_{30}, \mathrm{~F} 2=\mathrm{N}_{60}+\mathrm{P}_{30}+\mathrm{K}_{30}\right.$ and $\left.\mathrm{F} 3=\mathrm{N}_{60}+\mathrm{P}_{30}+\mathrm{K}_{30}+\mathrm{S}_{30} \mathrm{~kg} / \mathrm{ha}\right)$, were laid out in a split plot design, with 3 replications. Coriander variety 'CS-6' was used. The seeds were sown in furrows, spaced $30 \mathrm{~cm}$ apart on $16^{\text {th }}$ Oct., in 200203 and $23^{\text {rd }}$ Oct. in 2003-04, keeping a seed rate of $15 \mathrm{~kg} / \mathrm{ha}$. All herbicides was applied, as per emergence at 2 days after sowing (DAS), while hand weeding was done at 30 and 45 DAS, as per treatments. Half dose of $\mathrm{N}$ and full dose of P, K and $\mathrm{S}$ was applied basal through urea, DAP, MOP and gypsum, and remaining half dose of $\mathrm{N}$ was top dressed at 30 DAS. Each experimental plot was surveyed using $0.25 \mathrm{~m}^{2}$ quadrate, for studying weed composition at different stages and then converted into number of weeds $/ \mathrm{m}^{2}$. The data on weed density were subjected to square root transformation $\sqrt{ }(\mathbf{x}+\mathbf{0 . 5})$, to normalize their distribution. The relative density of prominent weeds at 30,60 DAS and at harvest was calculated, by following formula.

$$
\text { Relative Weed Density }(\%)=\frac{\text { Number of Individuals of the same species }}{\text { Number of Individuals of all species }} \quad \times 100
$$

The dry weight of category wise weeds was recorded at the time of 30, 60 and 90 DAS, and dried in oven at $70^{\circ} \mathrm{C}$ for 24 hours and weighed, to obtain weed dry matter. Weed control efficiency at harvest was worked by the following formula:

$$
\text { Weed Control Efficiency }(\%)=\frac{\text { Dry matter of weeds in contol plot }- \text { Dry matter of weeds in treated plot }}{\text { Dry matter of weeds in contol plot }}
$$

\section{RESULTS AND DISCUSSIONS}

\section{Weed Density}

The major weed flora comprised Goose foot (Chenopodium murale L.), Corn spurry (Spergula arvensis L.), Indian sweet clover (Melilotus indica L.), Scarlet pimpernel (Anagallis arvensis L.), Common lambsquarters (Chenopodium album L.), Field bindwind (Convolvulus arvensis L.), Purple nutsedge (Cyperus rotundus L.) and Bermudagrass (Cynodon dactylon L.). Among them, Goose foot (Chenopodium murale L.), Corn spurry (Spergula 
arvensis L.) among dicots and Purple nutsedge (Cyperus rotundus L.) among monocots were found most dominant weeds at all stages of crop growth. The species wise density of weed flora reported at 30, 45, 60, 75, 90 DAS and harvest of crop under weed management practices and balanced fertilization is depicted in Figure 1. All weed management practices affects weed flora population, as compared to weedy check and lowest population was reported by two HW at 30 and 45 DAS followed by pendimethalin $1.0 \mathrm{~kg} / \mathrm{ha}+$ one $\mathrm{HW}$ at 45 DAS treatments. An examination of data in Table 1 indicates that relative density of all weeds fluctuated to a great extent, due to different weed management practices at crop growth stages. Dicot dominant weeds Chenopodium murale and Spergula arvensis and monocot weed Cyperus rotundus, together constituted 57.31, 56.71 and 52.73 percent of total weed density, at 30 DAS, 60 DAS and at harvest, respectively and Chenopodium murale alone shared 24.50, 24.44 and 22.12 percent, respectively, at these stages of crop growth. Greater density of Chenopodium murale, Spergula arvensis and Cyperus rotundus may be due to the fact that, these weeds have quick germination and survival capacity, as well as greater competitive ability than other weeds. The result of present investigation shows that, dicot weeds were more dominating in the crop, during both the years.

\section{Weed Dry Weight, Weed Control Efficiency and Seed Yield}

The maximum dry weight of monocot, dicot and total weeds was recorded in control (Table 2). The herbicides, hand weeding and their integration lowered the dry weight of weeds at 30,60 and 90 DAS, as compared to control. Treatment two HW at 30 and 45 DAS caused maximum decrease in dry matter of monocot, dicot and total weeds at 30, 60 and $90 \mathrm{DAS}$, followed by pendimethalin $1.0 \mathrm{~kg} / \mathrm{ha}+$ one $\mathrm{HW}$ at $45 \mathrm{DAS}$. These treatments resulted effective and timely control of weeds, and did not allow weeds to regenerate and therefore, lower dry weight of weeds were recorded. The results are in agreement with the findings of Gora et al. (1996). The highest weed control efficiency (88.50\%) was recorded under two hand weedings, at 30 and $45 \mathrm{DAS}$, followed by pendimethalin $1.0 \mathrm{~kg} / \mathrm{ha}+\mathrm{HW}$ at $45 \mathrm{DAS}$ (88.14\%), followed by oxyflurofen $0.25 \mathrm{~kg} / \mathrm{ha}+\mathrm{HW}$ at 45 DAS (83.48 \%). Such findings were also reported by Sethivel (2001).

Among all the herbicidal treatments, metribuzin resulted in poorest weed contol over weedy check, especially at later stages, which might be due to its high water solubility and less persistence in soil system. On the other hand, oxyfluorfen and oxadiargyl were found inferior to pendimethalin, but significantly superior over weedy check. Oxyflurofen and oxadiargyl excert their phototoxic effect, through contact action on germinating weeds. Pendimethalin being dinitroaniline, is known to be absorbed by germinating weeds and inhibits cell division in meristematic tissue, so that most of weeds die within few days of their emergence. Two HW at 30 and 45 DAS control early, as well as late flushes of weeds and crops attained good growth and seed yield. Application of pendimethalin, followed by One HW at 45 DAS performed very well in controlling weeds, because of the fact that, emergence and early growth of weeds was inhibited by pre emergence pendimethalin, whereas later emerging weeds were effectively controlled by implication of HW at 45 DAS. Similar, trends of results have also been reported by Choudhary (2000).

The highest seed yield (15.84 q/ha) of coriander was obtained, under two HW treatment, followed by pre emergence application of pendimethalin $1.0 \mathrm{~kg} / \mathrm{ha}+\mathrm{HW}$ at 45 DAS $(15.74 \mathrm{q} / \mathrm{ha})$ and both treatment remained at par to each other, but proved superior over rest of practices. The increase in seed yield with weed management measures is believed to be an indirect expression of reduction in weed crop competition, which significantly helped in increasing seed yield. Choudhary and Gupta (1991), also observed an increase in yield attributes and seed yield of cumin, through weed management practices. 


\section{Effect of Balanced Fertilization}

Balanced fertilization practices did not influence the weed density. However, balanced fertilization with $\mathrm{N}+\mathrm{P}+\mathrm{K}+\mathrm{S}$ tended to enhance monoct, dicot and total weed dry matter, over $\mathrm{N}+\mathrm{P}$ and $\mathrm{N}+\mathrm{P}+\mathrm{K}$, significantly (Figure 1 and Table 1). The profound effect of balanced fertilization on weed dry matter seems to be an overall influence of its role, in growth and development of plant. On the same way, balanced fertilization with $\mathrm{N}+\mathrm{P}+\mathrm{K}+\mathrm{S}$ also significantly enhanced crop seed yield, by 9.26 percent over $\mathrm{N}+\mathrm{P}$ fertilization and 8.36 percent over $\mathrm{N}+\mathrm{P}+\mathrm{K}$ fertilization. The significantly higher values of these parameters, with $\mathrm{N}+\mathrm{P}+\mathrm{K}+\mathrm{S}$ balanced nutrition could be ascribed to be due to exploitation of crop genetic potential, for vegetative and reproductive growth, upto greatest extent. The results corroborate with the findings of Tripathi et al. (2001).

\section{Interaction Effect}

Interactive effect of weed management and balanced fertilization was also found significant, in respect of monocot weed dry matter at 90 DAS and seed yield of coriander (Table 3). On pooled basis, minimum amount of monocot weed dry matter was reported under two $\mathrm{HW}$, with $\mathrm{N}+\mathrm{P}$ fertilization $(52.18 \mathrm{~kg} / \mathrm{ha})$. However, this treatment combination was found, at par with two $\mathrm{HW}$ with $\mathrm{N}+\mathrm{P}+\mathrm{K}$, pendimethalin $+\mathrm{HW}$ and oxyflurofen $+\mathrm{HW}$ with $\mathrm{N}+\mathrm{P}$ or $\mathrm{N}+\mathrm{P}+\mathrm{K}$ fertilization. On an average, 83.59 percent reduction in monocot weed dry matter was registered, due to two $\mathrm{HW}$ with $\mathrm{N}+\mathrm{P}$ fertilizer combination, as against weedy check plot fertilized with $\mathrm{N}+\mathrm{P}+\mathrm{K}+\mathrm{S}$, wherein maximum production of monocot weed dry matter $(318.07 \mathrm{~kg} / \mathrm{ha})$ was recorded.

Two hand weeded plots fertilized with $\mathrm{N}+\mathrm{P}+\mathrm{K}+\mathrm{S}$, recorded significantly higher seed yield (17.75 q/ha) of coriander, as compared to two $\mathrm{HW}$ with $\mathrm{N}+\mathrm{P}$ or $\mathrm{N}+\mathrm{P}+\mathrm{K}$ fertilization. Among herbicidal integrations, maximum seed yield $(17.72 \mathrm{~kg} / \mathrm{ha})$ was obtained, with pendimethalin $+\mathrm{HW}$, along with $\mathrm{N}+\mathrm{P}+\mathrm{K}+\mathrm{S}$ fertilization and this combination remained at par with two HW, combined with $\mathrm{N}+\mathrm{P}+\mathrm{K}+\mathrm{S}$ fertilization. Thus, it could be concluded that, weeds in coriander should be controlled by pre-emergence application pendimethalin $1.0 \mathrm{~kg} / \mathrm{ha}$, followed by one $\mathrm{HW}$ at 45 DAS and crop should be fertilized with $60 \mathrm{~kg} \mathrm{~N}+30 \mathrm{~kg} \mathrm{P}_{2} \mathrm{O}_{5}+30 \mathrm{~kg} \mathrm{~K} \mathrm{O}_{2}+30 \mathrm{~kg} \mathrm{~S} / \mathrm{ha}^{-1}$, to get higher seed yield.

\section{CONCLUSIONS}

A field experiment was conducted during winter seasons of 2002-03 and 2003-04 at Udaipur (Rajasthan), to study the effect of weed management and balanced fertilization on coriander. All the weed management practices effectively reduced the density of all weed species, at all stages of crop growth. Due to weed management practices, dry weight of weeds was reduced by 61.40 to 86.63 percent, at various stages of crop growth, compared to weedy check. The higher seed yield $(15.74 \mathrm{q} / \mathrm{ha})$ was obtained under pendimethalin $1.0 \mathrm{~kg} / \mathrm{ha}$, followed by one $\mathrm{HW}$ at $45 \mathrm{DAS}$. Amongst, balanced fertilization application of $60 \mathrm{~kg} \mathrm{~N}+30 \mathrm{~kg} \mathrm{P}+30 \mathrm{~kg}+30 \mathrm{~kg} \mathrm{~S} / \mathrm{ha}$ was found most effective fertilization practice in coriander.

\section{REFERENCES}

1. Choudhary G R and Gupta O P 1991. Response of cumin (Cuminum cyminum) to nitrogen application, weed control and sowing methods. Indian Journal of Agronomy 36: 212-216.

2. Gora D R, Meena N L and Shivran P L 1996. Effect of weed control and time of nitrogen application in cumin (Cuminum cyminum). Indian Journal of Agronomy 41: 500-501. 
3. Kushwaha H S, Tripathi M L and Singh V B 2002. Weed management in coriander (Coriandrum sativum). Second International Agronomy Congress, New Delhi, India, Nov. 26-30 pp. 985-987.

4. Sethivel T2001. Chemical weed control in rainfed coriander. Indian Journal of Agronomy 88: 532-533.

5. Iram Fatma Jafri, Ainul Haq Khan \& Mohd Gulfishan, Genomic Damage Induced by Individual and Combination Treatment of Gamma Rays and Ethyl Methane Sulphonate in Coriandrum Sativum L Var. Karishma, International Journal of Botany and Research (IJBR), Volume 3, Issue 2, June 2013, pp. 79-85

6. Tripathi A K, Pandya R K and Tripathi M L 2001. Effect of nitrogen, phosphorus and potassium on stem gall disease and yield of coriander. Annals of Plant Protection Sciences 9 : 337-339.

7. Choudhary, G R 2000. Weed population dynamics and fennel (Foeniculum vulgare) growth as influenced by intergrated weed management. Indian Journal of Agronomy 45: 421-428.
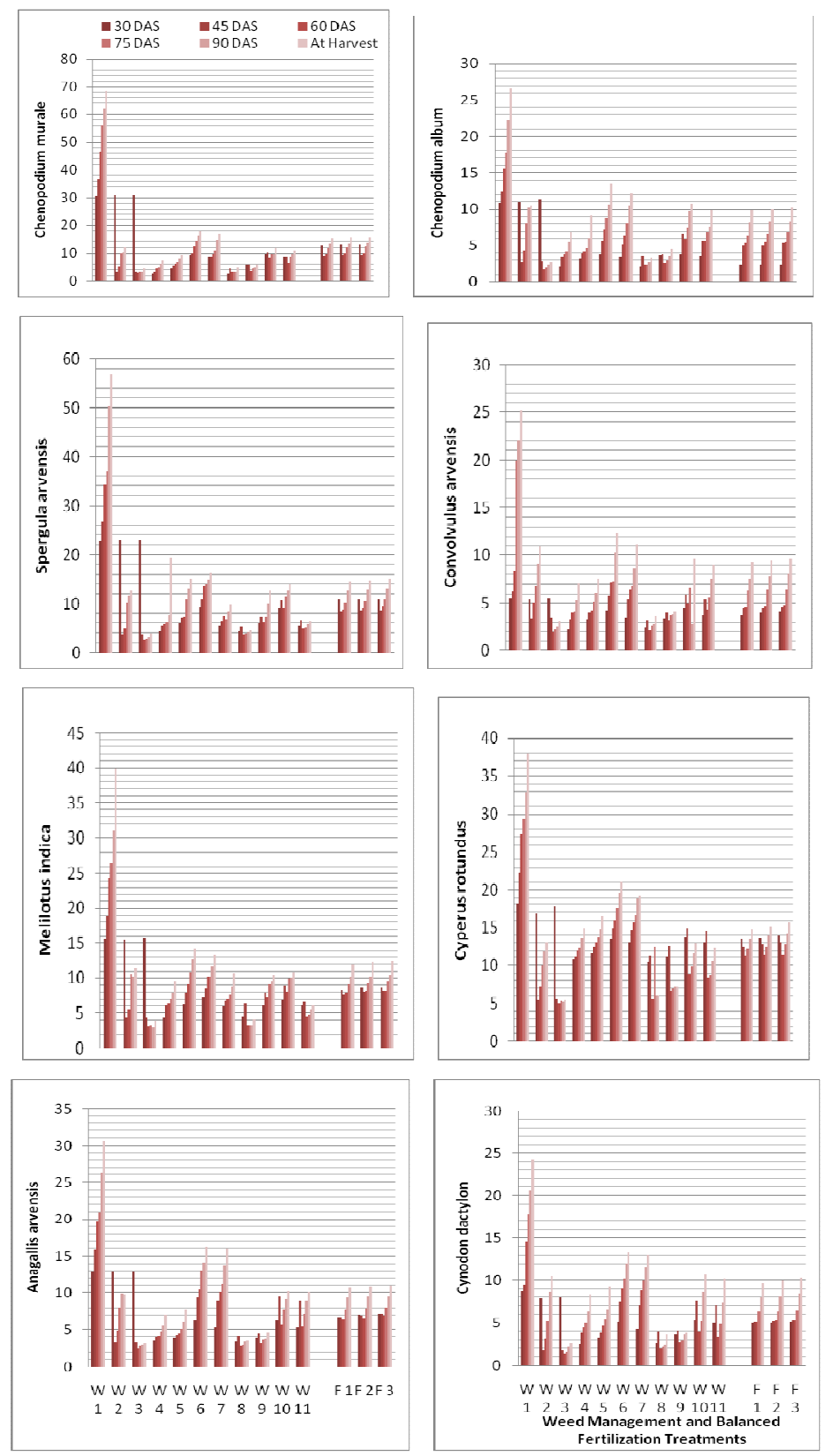

Figure 1: Density of Weed Flora at different Crop Growth Stages 
Table 1: Effect of Integrated Weed Management on Relative Density (\%) of Weed Flora in Coriander (Pooled Data of 2 Years)

\begin{tabular}{|c|c|c|c|c|c|c|c|c|c|c|c|c|}
\hline \multirow[t]{2}{*}{ Treatments } & \multicolumn{4}{|c|}{$30 \mathrm{DAS}$} & \multicolumn{4}{|c|}{$60 \mathrm{DAS}$} & \multicolumn{4}{|c|}{ At Harvest } \\
\hline & C.Murale & S. Arvensis & M. Indica & A. Arvensis & C. Murale & S. Arvensis & M. Indica & A. Arvensis & C.Murale & S. Arvensis & M. Indica & A. Arvensis \\
\hline Weedy check & 24.50 & 18.33 & 12.46 & 10.30 & 24.44 & 17.97 & 12.76 & 10.33 & 22.12 & 18.40 & 12.85 & 9.90 \\
\hline One HW (30 DAS) & 25.12 & 18.77 & 12.53 & 10.39 & 12.87 & 12.64 & 13.48 & 12.09 & 13.30 & 14.07 & 12.56 & 10.74 \\
\hline Two HW (30 and $45 \mathrm{DAS})$ & 24.67 & 18.41 & 12.63 & 10.34 & 13.78 & 12.22 & 14.58 & 11.74 & 14.75 & 13.92 & 13.07 & 10.96 \\
\hline Pendimethalin $1.0 \mathrm{~kg} / \mathrm{ha}$ & 8.06 & 13.43 & 13.29 & 10.85 & 9.73 & 12.97 & 14.22 & 9.27 & 10.51 & 13.65 & 13.54 & 9.90 \\
\hline Oxyfluorfen $0.25 \mathrm{~kg}$ ha & 10.66 & 14.42 & 14.93 & 9.33 & 11.38 & 13.93 & 17.10 & 8.48 & 10.47 & 17.07 & 15.91 & 8.84 \\
\hline Metribuzin $0.30 \mathrm{~kg} \mathrm{ha}$ & 15.46 & 16.16 & 12.04 & 10.99 & 14.45 & 15.81 & 11.93 & 12.21 & 14.44 & 13.23 & 10.80 & 13.13 \\
\hline Oxadiargyl $75 \mathrm{gha}$ & 17.18 & 11.32 & 11.95 & 10.87 & 13.36 & 10.70 & 9.70 & 14.14 & 15.49 & 9.01 & 9.82 & 14.68 \\
\hline $\begin{array}{l}\text { Pendimethalin } 1.0 \mathrm{~kg} / \mathrm{ha}+\mathrm{HW} \\
\text { (45DAS) }\end{array}$ & 8.18 & 13.33 & 13.78 & 10.54 & 13.71 & 14.30 & 12.82 & 11.24 & 14.16 & 13.52 & 11.83 & 10.63 \\
\hline $\begin{array}{l}\text { Oxyfluorfen } 0.25 \mathrm{~kg} / \mathrm{ha}+\mathrm{HW} \\
\text { (45DAS) }\end{array}$ & 13.00 & 14.09 & 14.11 & 8.91 & 10.57 & 17.84 & 19.90 & 9.15 & 10.66 & 24.02 & 19.62 & 8.62 \\
\hline $\begin{array}{l}\text { Metribuzin } 0.30 \mathrm{~kg} / \mathrm{ha}+\mathrm{HW}(45 \\
\text { DAS) }\end{array}$ & 16.44 & 15.38 & 11.57 & 10.81 & 15.21 & 16.76 & 14.52 & 10.43 & 12.97 & 15.53 & 11.82 & 11.37 \\
\hline $\begin{array}{l}\text { Oxadiargyl } 75 \text { gha + HW ( } 45 \\
\text { DAS) }\end{array}$ & 17.13 & 11.22 & 11.73 & 10.63 & 14.49 & 11.52 & 10.74 & 12.98 & 14.47 & 8.61 & 8.10 & 13.61 \\
\hline & C. Album & C. Arvensis & C. Rotundus & C. Dactylon & C. Album & C. Arvensis & C. Rotundus & C. Dachilon & C. Album & C. Arvensis & C. Rotundus & C. Dactylon \\
\hline Weedy check & 8.59 & 4.39 & 14.48 & 6.97 & 8.18 & 4.39 & 14.30 & 7.65 & 8.58 & 8.14 & 12.21 & 7.83 \\
\hline OneHW(30 DAS) & 8.74 & 4.37 & 13.67 & 6.43 & 10.31 & 12.53 & 18.24 & 7.86 & 11.53 & 12.05 & 14.29 & 11.48 \\
\hline Two HW (30 and 45 DAS) & 8.96 & 4.40 & 14.20 & 6.41 & 8.05 & 9.29 & 23.94 & 6.41 & 9.19 & 10.58 & 18.78 & 8.80 \\
\hline Pendimethalin $1.0 \mathrm{~kg} / \mathrm{ha}$ & 6.29 & 7.00 & 33.39 & 7.73 & 8.38 & 8.91 & 26.56 & 9.97 & 9.65 & 9.98 & 21.00 & 11.79 \\
\hline Oxyfluorfen $0.25 \mathrm{~kg}$ ha & 7.64 & 7.76 & 27.68 & 7.66 & 7.69 & 8.01 & 24.57 & 8.85 & 10.23 & 8.42 & 18.63 & 10.45 \\
\hline Metribuzin $0.30 \mathrm{~kg} \mathrm{ha}$ & 6.27 & 7.11 & 23.05 & 8.93 & 8.29 & 8.21 & 18.63 & 10.48 & 10.88 & 9.94 & 16.91 & 10.69 \\
\hline Oxadiargyl $75 \mathrm{gha}$ & 6.87 & 6.96 & 26.22 & 8.64 & 8.92 & 9.05 & 21.82 & 12.33 & 11.12 & 10.23 & 17.70 & 11.98 \\
\hline $\begin{array}{l}\text { Pendimethalin } 1.0 \mathrm{~kg} / \mathrm{ha}+\mathrm{HW} \\
\text { (45 DAS) }\end{array}$ & 5.28 & 7.37 & 32.28 & 8.03 & 8.92 & 8.72 & 22.18 & 8.17 & 9.81 & 10.88 & 18.32 & 10.89 \\
\hline $\begin{array}{l}\text { Oxyfluorfen } 0.25 \mathrm{~kg} / \mathrm{ha}+\mathrm{HW} \\
\text { (45DAS) }\end{array}$ & 8.25 & 7.65 & 25.58 & 8.42 & 7.03 & 8.89 & 19.06 & 7.61 & 8.35 & 7.80 & 13.70 & 7.25 \\
\hline $\begin{array}{l}\text { Metribuzin } 0.30 \mathrm{~kg} / \mathrm{ha}+\mathrm{HW}(45 \\
\text { DAS) }\end{array}$ & 6.21 & 7.46 & 23.19 & 8.97 & 10.65 & 8.88 & 16.41 & 7.17 & 11.69 & 10.66 & 14.19 & 11.79 \\
\hline $\begin{array}{l}\text { Oxadiargyl } 75 \text { g/ha + HW (45 } \\
\text { DAS) }\end{array}$ & 6.85 & 7.36 & 25.44 & 9.67 & 13.00 & 10.24 & 19.15 & 7.88 & 13.02 & 11.95 & 16.57 & 13.70 \\
\hline
\end{tabular}

DAS= Days After Sowing

Table 2: Effect of Integrated Weed Management and Balanced Fertilization on Dry Weight of Weeds, Weed Control Efficiency and Seed Yield of Coriander (Pooled Data of 2 Years)

\begin{tabular}{|c|c|c|c|c|c|c|c|c|c|c|c|}
\hline \multirow{3}{*}{ Treatments } & \multicolumn{9}{|c|}{ Dry Weight of Weeds (kg/ha) } & \multirow{3}{*}{$\begin{array}{l}\text { Weed Control } \\
\text { Efficiency (\%) }\end{array}$} & \multirow{3}{*}{$\begin{array}{l}\text { Seed } \\
\text { Yield } \\
(\mathrm{q} / \mathrm{ha})\end{array}$} \\
\hline & \multicolumn{3}{|c|}{30 DAS } & \multicolumn{3}{|c|}{$60 \mathrm{DAS}$} & \multicolumn{3}{|c|}{90 DAS } & & \\
\hline & Monocot & Dicot & Total & Monocot & Dicot & Total & Monocot & Dicot & Total & & \\
\hline \multicolumn{12}{|l|}{ Weed Management } \\
\hline Weedy check & 274.69 & 409.97 & 684.66 & 208.35 & 708.04 & 916.39 & 367.97 & 1377.13 & 1745.10 & - & 5.27 \\
\hline One HW (30 DAS) & 31.96 & 65.42 & 97.38 & 101.83 & \begin{tabular}{|l|}
121.11 \\
\end{tabular} & 222.93 & 178.06 & 259.80 & 437.87 & 71.13 & 12.31 \\
\hline Two HW (30 and 45 DAS) & 28.88 & 62.60 & 91.48 & 31.13 & 69.01 & 100.15 & 62.68 & 123.58 & 186.25 & 88.50 & 15.84 \\
\hline Pendimethalin $1.0 \mathrm{~kg} / \mathrm{ha}$ & 31.38 & 75.62 & 107.01 & 67.73 & 111.16 & 178.89 & 192.24 & 296.68 & 488.92 & 66.70 & 10.40 \\
\hline Oxyfluorfen $0.25 \mathrm{~kg} / \mathrm{ha}$ & 34.19 & 80.23 & 114.42 & 71.32 & 146.46 & 217.78 & 203.37 & 325.13 & 528.50 & 63.34 & 8.99 \\
\hline Metribuzin $0.30 \mathrm{~kg} / \mathrm{ha}$ & 41.75 & 86.39 & 128.13 & 108.70 & 231.46 & 340.16 & 215.93 & 457.55 & 673.48 & 51.71 & 8.27 \\
\hline Oxadiargyl $75 \mathrm{~g} / \mathrm{ha}$ & 37.53 & 83.51 & 121.04 & 108.33 & 208.05 & 316.38 & 209.74 & 421.41 & 631.15 & 53.38 & 8.53 \\
\hline Pendimethalin $1.0 \mathrm{~kg} / \mathrm{ha}+\mathrm{HW}$ (45 DAS) & 30.44 & 68.27 & 98.71 & 33.57 & 70.38 & 103.95 & 66.71 & 130.33 & 197.03 & 88.14 & 15.74 \\
\hline Oxyfluorfen $0.25 \mathrm{~kg} / \mathrm{ha}+\mathrm{HW}$ (45 DAS) & 33.53 & 72.74 & 106.26 & 37.24 & 95.24 & 132.48 & 71.77 & 196.90 & 268.66 & 83.48 & 13.26 \\
\hline Metribuzin $0.30 \mathrm{~kg} / \mathrm{ha}+\mathrm{HW}(45 \mathrm{DAS})$ & 40.55 & 82.57 & 123.12 & 100.73 & 117.28 & 218.70 & 155.07 & 228.35 & 383.42 & 72.74 & 12.48 \\
\hline Oxadiargyl $75 \mathrm{~g} / \mathrm{ha}+\mathrm{HW}$ (45 DAS) & 38.60 & 76.16 & 114.76 & 87.25 & 106.27 & 193.52 & 144.57 & 207.45 & 352.01 & 74.35 & 12.77 \\
\hline $\mathrm{CD}(\mathrm{P}=0.05)$ & 7.04 & 13.11 & 12.05 & 7.49 & 19.37 & 9.15 & 16.39 & 39.83 & 45.53 & - & 0.80 \\
\hline \multicolumn{12}{|l|}{ Balanced Fertilization (kg/ha) } \\
\hline $60 \mathrm{~N}+30 \mathrm{P}$ & 52.40 & 95.97 & 148.37 & 75.60 & 156.34 & 231.94 & 163.77 & 341.68 & 505.45 & 66.97 & 10.33 \\
\hline $60 \mathrm{~N}+30 \mathrm{P}+30 \mathrm{~K}$ & 56.41 & 106.18 & 162.59 & 86.75 & 180.65 & 267.39 & 175.81 & 366.09 & 533.47 & 64.86 & 11.25 \\
\hline $60 \mathrm{~N}+30 \mathrm{P}+30 \mathrm{~K}+30 \mathrm{~S}$ & 61.23 & 115.16 & 176.40 & 98.43 & 204.42 & 302.85 & 186.48 & 389.76 & 568.10 & 62.75 & 12.19 \\
\hline $\mathrm{CD}(\mathrm{P}=0.05)$ & 2.99 & 4.26 & 5.51 & 3.67 & 8.82 & 9.15 & 7.46 & 15.89 & 18.62 & - & 0.34 \\
\hline
\end{tabular}

$\mathrm{DAS}=$ Days after Sowing

Table 3: Interaction Effect of Integrated Weed Management and Balanced Fertilization on Weed Dry Matter and Seed Yield of Coriander (Pooled Data of 2 Years)

\begin{tabular}{|l|c|c|c|c|c|c|}
\hline \multirow{2}{*}{ Weed Management } & \multicolumn{3}{|c|}{$\begin{array}{c}\text { Monocot Weed Dry Matter } \\
\text { (Kg/Ha) At 90 DAS }\end{array}$} & \multicolumn{3}{c|}{ Seed Yield ( q/ha) } \\
\hline & N+P & N+P+K & N+P+K+S & N+P & N+P+K & N+P+K+S \\
\hline Weedy check & 391.06 & 394.79 & 318.07 & 5.24 & 5.26 & 5.31 \\
\hline One HW (30 DAS) & 171.32 & 171.58 & 191.30 & 12.21 & 12.27 & 12.46 \\
\hline $\begin{array}{l}\text { Two HW (30 and 45 } \\
\text { DAS) }\end{array}$ & 52.18 & 57.29 & 78.57 & 14.07 & 15.71 & 17.75 \\
\hline Pendimethalin 1.0 kg/ha & 183.25 & 186.78 & 206.70 & 9.77 & 10.65 & 10.77 \\
\hline Oxyfluorfen 0.25 kg/ha & 196.62 & 197.96 & 215.53 & 8.42 & 9.24 & 9.32 \\
\hline Metribuzin 0.30 kg/ha & 208.49 & 209.35 & 229.97 & 7.84 & 8.59 & 8.37 \\
\hline
\end{tabular}




\begin{tabular}{|l|c|c|c|c|c|c|}
\hline \multicolumn{7}{|c|}{ Table 3: Contd., } \\
\hline Oxadiargyl 75 g/ha & 194.93 & 207.68 & 226.62 & 8.04 & 8.78 & 8.77 \\
\hline $\begin{array}{l}\text { Pendimethalin 1.0 kg/ha } \\
\text { + HW (45 DAS) }\end{array}$ & 58.50 & 60.25 & 81.39 & 14.00 & 15.51 & 17.72 \\
\hline $\begin{array}{l}\text { Oxyfluorfen 0.25 kg/ha } \\
\text { + HW (45 DAS) }\end{array}$ & 61.62 & 66.65 & 87.05 & 11.74 & 13.05 & 14.98 \\
\hline $\begin{array}{l}\text { Metribuzin 0.30 kg/ha + } \\
\text { HW (45 DAS) }\end{array}$ & 47.87 & 149.20 & 168.15 & 11.04 & 12.15 & 14.24 \\
\hline $\begin{array}{l}\text { Oxadiargyl 75 g/ha + } \\
\text { HW (45 DAS) }\end{array}$ & 135.61 & 139.61 & 158.48 & 11.30 & 12.56 & 14.26 \\
\hline $\begin{array}{l}\text { CD (P=0.05) for balanced fertilization at } \\
\text { same weed management practice }\end{array}$ & 24.74 & & & 1.14 \\
\hline $\begin{array}{l}\text { CD (P=0.05) for weed management at same } \\
\text { level of balanced fertilization }\end{array}$ & 25.84 & & & 1.22 \\
\hline
\end{tabular}


